J. Clin. Chem. Clin. Biochem.

Vol. 15, 1977, pp. 635-644

\title{
Agarose Gel Electrophoresis of Cerebrospinal Fluid Proteins and Analysis of the Pherogram Profiles by Analog Computer ${ }^{1}$ )
}

\author{
By $M$. Siegert and $H$. Siemes
}

Interdisziplinäre Arbeitsgruppe für Klinische und Experimentelle Plasmaproteinforschung

Fachbereich Veterinärmedizin der Freien Universität und Kinderklinik und Poliklinik der Freien Universität Berlin

(Received May 21, 1976/June 20, 1977)

Summary: A micro-method of agarose gel electrophoresis requiring 1-3 ml of cerebrospinal fluid for quantitative analysis of cerebrospinal fluid proteins is described. After concentration of CSF to about $50 \mu \mathrm{l}$ by ultrafiltration and refractometric determination of protein, approximately 20-40 $\mu \mathrm{g}$ of total protein are used for electrophoresis. Photometric scanning of the electrophoretic pattern at two different wavelengths permits quantitative evaluation. The pherograms are analysed by means of a modified DU-PONT analog computer. Factors which influence quantitative electrophoresis are examined. In cerebrospinal fluid of normal children 15 protein fractions are demonstrated: 2 prealbumins, albumin, $5 \alpha-, 3 \beta$ - and $4 \gamma$-globulins.

\section{Agarosegelelektrophorese von Liquorproteinen und Analyse der Pherogrammprofile mit dem Analogrechner}

Zusammenfassung: Es wird ein Mikroverfahren zur quantitativen Elektrophorese der Liquorproteine in Agarosegel beschrieben. Zur Analyse sind 1-3 ml Liquor cerebrospinalis erforderlich. Nach der Einengung mittels Ultrafiltration auf $50 \mu \mathrm{l}$ und der refraktometrischen Eiweißbestimmung im Konzentrat werden ca. 20-40 $\mu \mathrm{g}$ Gesamtprotein zur Elektrophorese eingesetzt. Die Photometrie des Elektrophoresemusters bei 2 verschiedenen Wellenlängen erlaubt eine quantitative Auswertung. Die Analyse der Pherogramme erfolgt mit einem modifizierten DU-PONT Analogrechner. Es werden Faktoren untersucht, welche die quantitative Elektrophorese beeinflussen. Im Liquor cerebrospinalis normaler Kinder können 15 Proteinfraktionen nachgewiesen werden: 2 Präalbumine, Albumin, $5 \alpha-, 3 \beta$ - und $4 \gamma$-Globuline.

\section{Introduction}

Systematic electrophoretic investigations of the cerebrospinal fluid (CSF) proteins have improved the possibilities of diagnosing neurological disorders such as multiple sclerosis (1-6). Agar gel electrophoresis which has been used by a number of authors $(7-12)$ is particularly suitable for resolving CSF proteins into a broad spectrum of fractions. Whether quantitative evaluation is reliable for the elucidation of central nervous system's pathophysiology is still a matter of controversy (9). Any modification of zone electrophoresis causes deviation of quantitative reșults (12). We have now revised the method of agar gel electrophoresis reported by Wieme (9) in order to develop a quantitative method producing precise results: Moreover this method should be suitable for analysing small quantities of CSF so that it can be applied as a diagnostic procedure in children.

\footnotetext{
1) With the support of the Deutsche Forschungsgemeinschaft
}

\section{Methods and Materials}

Ultrafiltration of CSF and determination of protein after concentration

The necessary concentration of the spinal fluid was carried out by an apparatus using collodium tubes made by "Sartorius Werke Göttingen". Concentration was not obtained by external vacuum in the usual way, but by internal pressure generated by a movable gravity piston with pressure-tight guide rings. This apparatus ensures a maximum filtration surface throughout the filtration procedure and a definite volume of concentrate without constant observation. In each case, $1-3 \mathrm{ml}$ were concentrated down to $50 \mu \mathrm{l}$. If the quantities available are very minute, a starting quantity of $0.5 \mathrm{ml}$ is permissible in exceptional cases.

To determine the protein concentration of the CSF after ultrafiltration, the Zeiss refractometer $A$ (special prisma $F$ 3) was used in conjunction with a calibration curve of a reference serum; $5 \mu l$ were required for each measurement.

Electrophoresis

Gel strips $(26 \times 76 \mathrm{~mm})$ on microscope slides were prepared from $9 \mathrm{~g} / \mathrm{l}$ Bio-Rad agarose (comparative tests were made with Difco Agar Noble) and barbital- $\mathrm{Na} / \mathrm{HCl}, 82 \mathrm{mmol} / \mathrm{l}$ buffer according to Wieme (9). To apply the concentrate, two grooves 
$1.5 \mathrm{~mm}$ deep and $5 \mathrm{~mm}$ wide were formed with a micrometer punch at a distance of $23 \mathrm{~mm}$ from the narrow side of the slides and a polyethylene micro-pipette was used after calibration according to Mattenheimer (14). As it is usually impossible to manufacture a pipette with the optimum volume of $1.5 \mu l$, the pipette actually used had a volume of $1.6 \mu \mathrm{l}$.

The applied volumes in relation to protein concentration are shown in table 1 . As a rule, $20-40 \mu \mathrm{g}=4-8 \mu \mathrm{g} / \mathrm{mm}$ slit were applied. Smaller quantities are permissible in exceptional cases, but $10 \mu \mathrm{g}=2 \mu \mathrm{g} / \mathrm{mm}$ represents the minimum.

Serum proteins were pipetted into the starting slit, diluted at $1: 5$ for determination of albumin and undiluted for investigation of globulins.

Electrophoretic separation of proteins was carried out in a modified Wieme chamber (15). In order to dissipate the heat produced by the electric current, we did not use the evaporation method as suggested by Wieme (9), but held the petrol ether surrounding the gel plates at a constant temperature of $5^{\circ} \mathrm{C}$ by means of a cooler. Each electrophoretic run lasted 29 minutes at $250 \mathrm{~V}$, using 3 gel strips.

Tab. 1. Protein concentration after ultrafiltration of 1-3 $\mathrm{ml}$ CSF; dilution of protein concentration and quantity of protein required for electrophoresis.

\begin{tabular}{rcrl}
\hline $\begin{array}{l}\text { Protein } \\
\text { Concentration }\end{array}$ & $\begin{array}{l}\text { Dilution } \\
\text { with } \\
9 \mathrm{~g} / \mathrm{l} \mathrm{NaCl}\end{array}$ & $\begin{array}{l}\text { Volume } \\
\text { applied }\end{array}$ & $\begin{array}{l}\text { Quantity of } \\
\text { protein } \\
\text { applied }\end{array}$ \\
\hline $25-50 \mathrm{~g} / 1$ & $1+1$ & $1.6 \mu \mathrm{l}$ & $20-40 \mu \mathrm{g}$ \\
& $1+2$ & $1.6 \mu \mathrm{l}$ & $13-26 \mu \mathrm{g}$ \\
$12.5-25 \mathrm{~g} / 1$ & - & $1.6 \mu \mathrm{l}$ & $20-40 \mu \mathrm{g}$ \\
& $1+1$ & $1.6 \mu \mathrm{l}$ & $10-20 \mu \mathrm{g}$ \\
$8.0-12.5 \mathrm{~g} / \mathrm{l}$ & - & $2 \times 1.6 \mu \mathrm{l}$ & $26-40 \mu \mathrm{g}$ \\
& - & $1.6 \mu \mathrm{l}$ & $13-20 \mu \mathrm{g}$ \\
$8.0 \mathrm{~g} / \mathrm{l}$ & - & $3 \times 1.6 \mu \mathrm{l}$ & $38.4 \mu \mathrm{g}$ \\
& - & $2 \times 1.6 \mu \mathrm{l}$ & $25.6 \mu \mathrm{g}$ \\
\hline
\end{tabular}

\section{Buffer solution}

After fixation with $5 \%$ alcoholic acetic acid for one hour, the 3 gel strips held in a plexiglass frame were washed in 2 litres of distilled water for 12 hours in order to extract the buffer salts, and afterwards dried in an incubator at $35^{\circ} \mathrm{C}$.

In comparative tests, proteins were fixed by a saturated solution of picric acid in $200 \mathrm{~g} / 1$ acetic acid, and buffer salts were extracted by means of filter paper.

60 carriers at a time were stained by uniform shaking in an automatic stainer (staining time $30 \mathrm{~min}, 4$ successive decolorizing baths for $5 \mathrm{~min}$ ). Dye: $50 \mathrm{~g}$ Amido Black $10 \mathrm{~B}$, and $50 \mathrm{ml}$ glacial acetic acid, made up to $1000 \mathrm{ml}$ with distilled water; Washing solution: $20 \mathrm{ml}$ glacial acetic acid diluted with distilled water to $1000 \mathrm{ml}$.

\section{Photometric scanning}

To plot the CSF pherograms, a Zeiss chromatogram spectrophotometer (slit width $0.04 \mathrm{~mm}$ ) was used in combination with a W \& W extinction recorder Type 3212. The feed rate of the photometer table was $15 \mathrm{~mm} / \mathrm{min}$, that of the recorder $10 \mathrm{~cm} /$ $\mathrm{min}$. At first the pherograms of the CSF specimens were recorded at a wavelenght of $610 \mathrm{~nm}$ within the absorbance range $0-1$, and in case of low protein concentrations in the range $0-0.5$. Then the unregistered albumin was plotted at a wavelength of $482 \mathrm{~nm}$ at the minimum of the absorption curve of Amido Black $10 \mathrm{~B}$ and the integration values thus obtained converted by means of factor 3.71 to the scale of $610 \mathrm{~nm}$.
Serum pherograms were recorded at $482 \mathrm{~nm}$ (range of absorbance 0-1).

An albumin calibration curve was established by registration at $482 \mathrm{~nm}$ within the absorbance range of $0-1$ or $1-2$ after automatic switchover of the recorder.

Evaluation of the electrophoretic profiles by analog computer

The pherogram curves were resolved into normal distributions (Gaussian), corresponding to individual protein fractions, by means of a modified DU PONT analog computer (Curve resolver 310). Each of 18 function generators contained in the apparatus can construct one normal distribution independently of the others. The three parameters, height, width, and position, that define the size and the horizontal position of a normal distribution on the screen can be controlled by three potentiometers for each generator. By means of a mirror system the computer curve is superimposed on the pherogram curve, thus making both simultaneously visible. The Gaussian distributions were determined by adjusting the potentiometers successively until the sum of the individual distributions corresponded to the curve of the pherogram. Then the areas of the protein fractions were computed from the values of the adjusted parameters.

In order to determine the integral values of the albumin distributions incompletely registered at $610 \mathrm{~nm}$, the area of the albumin peak recorded at $482 \mathrm{~nm}$ was integrated separately before the analysis of prealbumin and globulins. The value obtained was converted by means of the factor 3.71 (calculated by means of 10 different albumin spots) to the scale of $610 \mathrm{~nm}$ and fed directly into the computer.

The distance from the albumin centre (39.5) to the application slit $(100)$ was adopted as the reference length for determining the horizorital positions of the fractions in the curve corresponding to electrophoretic mobility. The positions of the pre-albumin fractions were therefore located in the range below 39.5 and the positions of the immunoglobulins, displaced towards the cathode as a result of electro-osmosis, were found above 100 , figure 1 .

To analyse the pherogram curves completely, the capabilities of the DU PONT analog computer had to be completely redesigned. The number of generators was increased from 10 to 18 . Digital readouts were installed for the integrals and the positions of the heights and widths of the fractions and the integrals of the Gaussian distributions. An additional unit was incorporated for direct input of the separately ascertained albumin values. A computer was designed to store the individual values and calculate the relative distributions as percentages. Individual values were recorded by a teleprinter, the original and synthesized curves by an XY writer. The block diagram of the computer is shown in figure 2

\section{Cerebrospinal fluids}

Lumbar CSF of 38 children aged 2 to 14 years was stored for electrophoresis at a temperature of $4^{\circ} \mathrm{C}$ for a maximum of one week. In order to establish "normal values" of CSF, the following criteria were applied to the symptoms and findings of the children examined:

1. Only slight impairment of the child's general health by the acute illness.

2. Apart from meningism, which could not be eliminated with certainty, no signs of neurological disease.

3. No previous convuisions.

4. Normal serum electropherogram, apart from an $\alpha_{2}$ globulin increase indicating the acute infection (since severe dysproteinaemia is reflected in the CSF).

5. Normal CSF findings: cell count up to $3-(5) \cdot 10^{6} / 1$, total protein concentration $100=300 \mathrm{mg} / \mathrm{l}$, glucose concentration $100-300 \mathrm{mg} / \mathrm{l}$. (1/2-2/3 of the blood sugar concentration).

Due to the understandable scarcity of CSF protein, serum was used for the methodical study of the influence of various gels, methods of extraction of buffer salts and fixation on the results of electrophoresis. 


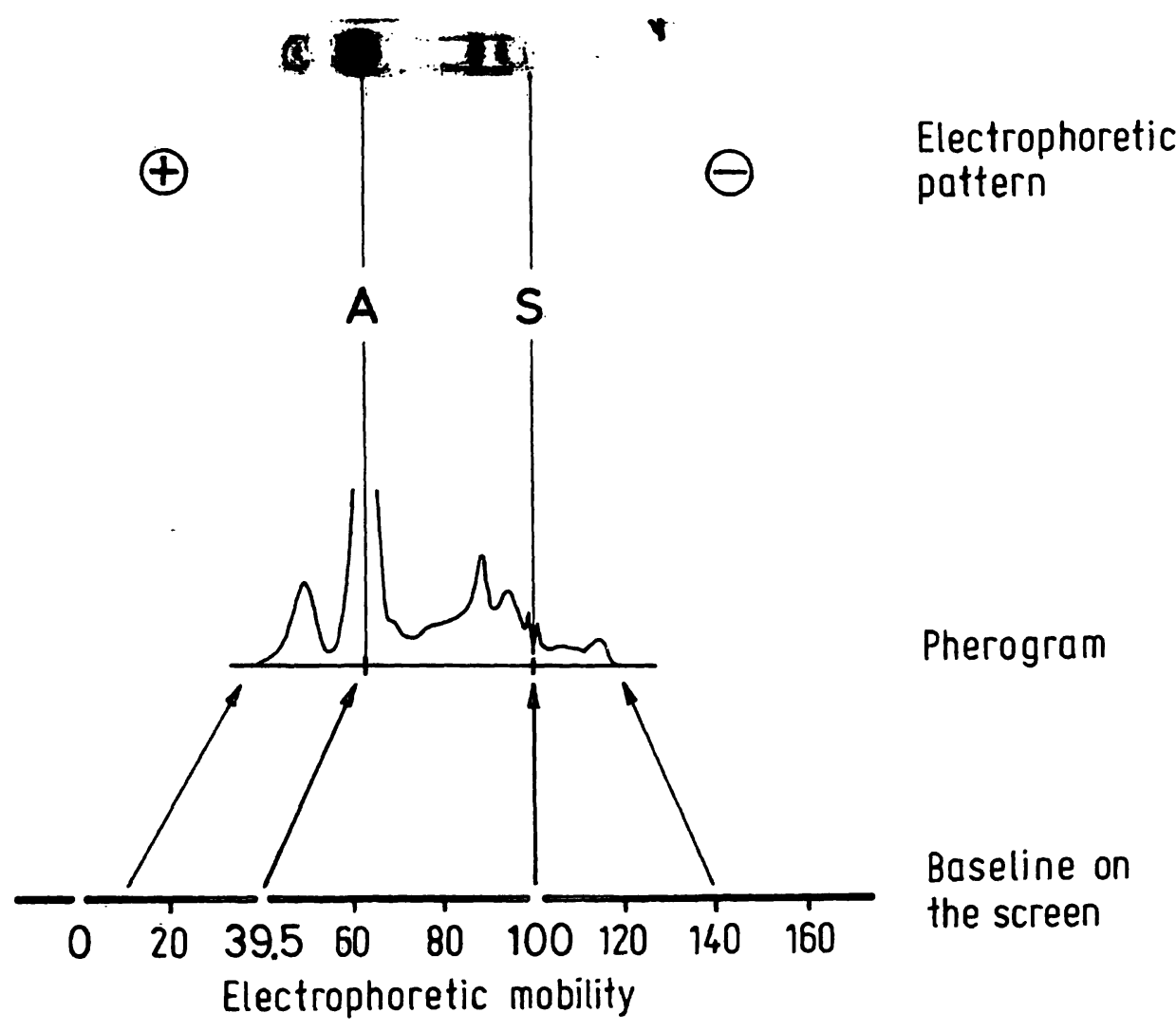

Fig. 1. Evaluation of electrophoretic mobility of protein fractions. Fixed marks in the baseline on the screen of the analog computer (albumin $(A)=39.5$ and application slit $(S)=100$ ) were adjusted to the actual pherogram. The horizontal position of all protein fractions were then related to the extensible scale.

Results

Influence of agar gel and agarose gel as carriers and of two methods of extracting buffer salts and fixation on quantitative electrophoresis

Serum electrophoresis was carried out on 32 plates, using agar gel in one group and agarose gel in the other. For the albumin determination, the serum was diluted $1: 5$, while it remained undiluted for the globulin determination. One sample was applied to one gel plate in 2 adjacent slits in each case. After electrophoretic separation and fixation of the proteins in alcoholic acetic acid, the buffer salt was extracted from half the plates of each gel type by two different methods:

1. drying by means of filter paper

2. washing for 12 hours in distilled water.

From table 2 it can be seen that, after extraction of the buffer salts by the same technique, the highest integration values were obtained for agarose gel. This finding is due to the high pyruvate and sulphate content of agar, as the acid groups of the carrier mask the dye-absorbing groups of the protein. The globulins, spread over a large range of the pherogram, are more strongly affected than albumin, which is confined to a small space. In this way, an apparent loss of protein and a shift of the albumin-globulin ratio in the pherogram can be explained when agar is used.
Albumin amounted to $57.6 \%$ of total protein in agarose gel pherograms (Group I) against $64.0 \%$ in agar pherograms (Group III).

The method of extracting buffer salts had an even greater influence on quantitative electrophoresis than the gel type. When the buffer salts were extracted from agarose gel with filter paper, considerable protein loss occurred. . Average total integration values of 1505 IE were found with filter paper (Group II), 2444 IE after washing (Group I). By staining the filter papers used to cover the agarose gel plates (Group II), it was proved that during the dying process a large part of the albumin had penetrated into the filter paper. With agarose gel as the carrier, extraction of buffer salts with filter paper led to a considerable falsification of the results, which became apparent not only in a reduction of total protein content, but also in a displacement of the albumin-globulin ratio (compare Group I and II).

When agar was used instead of agarose gel, smaller quantities of protein penetrated into the covering filter paper. In comparison with the stained filter paper strips of Group II, those used for Group IV showed considerably less staining, which was clearly apparent in the albumin range. This can be attributed to the high sulphate and pyruvate content of agar. The acid groups of agar obviously exercise an additional binding effect on the proteins contained in the gel. 
Tab. 2. Effect of two methods of extracting buffer salts on the quantitative result of electrophoresis in agarose and agar gel. IE = integrator units; $s=$ standard deviation; $\%=$ percentage of total protein; $\mathrm{CV}=$ coefficient of variation.

\begin{tabular}{|c|c|c|c|c|c|}
\hline Gel & Group & $\begin{array}{l}\text { Method of buffer } \\
\text { salt extraction }\end{array}$ & Total protein & Albumin & Globulin \\
\hline \multirow[b]{2}{*}{ Agarose } & I & $\begin{array}{l}\text { washing with } \\
\text { distilled water }\end{array}$ & $\begin{aligned} \bar{x} & =2444 \mathrm{IE} \\
& =100 \%\end{aligned}$ & $\begin{aligned} \bar{x} & =1.407 \mathrm{IE} \\
& \equiv 57.57 \% \\
s & =81.80 \mathrm{IE} \\
C V & =5.81 \%\end{aligned}$ & $\begin{aligned} \bar{x} & =1037 \mathrm{IE} \\
& =42.43 \% \\
s & =79.81 \mathrm{IE} \\
C V & =7.69 \%\end{aligned}$ \\
\hline & II & $\begin{array}{l}\text { covering with } \\
\text { filter paper }\end{array}$ & $\begin{aligned} \overline{\mathbf{x}} & =1505 \mathrm{IE} \\
& =100 \%\end{aligned}$ & $\begin{aligned} \bar{x} & =571 \mathrm{IE} \\
& =37.9 \% \\
\mathrm{~s} & =176.5 \mathrm{IE} \\
\mathrm{CV} & =30.9 \%\end{aligned}$ & $\begin{aligned} \overline{\mathbf{x}} & =934 \mathrm{IE} \\
& =62.1 \\
\mathrm{~s} & =99.06 \mathrm{IE} \\
\mathrm{CV} & =10.6 \%\end{aligned}$ \\
\hline \multirow[b]{2}{*}{ Agar } & III & $\begin{array}{l}\text { washing with } \\
\text { distilled water }\end{array}$ & $\begin{aligned} \overline{\overline{\mathrm{x}}} & \equiv 1486 \mathrm{IE} \\
& =100 \%\end{aligned}$ & $\begin{aligned} \overline{\mathrm{x}} & =951 \mathrm{IE} \\
& =63.99 \% \\
\mathrm{~s} & =54.39 \mathrm{IE} \\
\mathrm{CV} & =5.72 \%\end{aligned}$ & $\begin{aligned} \overline{\mathrm{x}} & =535 \mathrm{IE} \\
& =36.00 \% \\
\mathrm{~s} & =53.86 \mathrm{IE} \\
\mathrm{CV} & =10.07 \%\end{aligned}$ \\
\hline & IV & $\begin{array}{l}\text { covering with } \\
\text { filter paper }\end{array}$ & $\begin{aligned} \overline{\mathrm{x}} & =1699 \mathrm{IE} \\
& =100 \%\end{aligned}$ & $\begin{aligned} \overline{\mathbf{x}} & =1098 \mathrm{IE} \\
& =64.63 \% \\
\mathrm{~s} & =62.08 \mathrm{IE} \\
C \mathrm{~V} & =5.65 \%\end{aligned}$ & $\begin{aligned} \bar{x} & =601 \mathrm{IE} \\
& =35.37 \% \\
s & =66.19 \mathrm{IE} \\
\mathrm{CV} & =11.01 \%\end{aligned}$ \\
\hline
\end{tabular}

The highest integration values and the greatest probability of an undistorted result were obtained with agarose gel from which the buffer salts were carefully extracted by washing. It remains unclarified why significantly lower integration values are found with Group III (agar gel, washed) in contrast to Group IV (agar gel, covered with filter paper).

The fixing effect of alcoholic acetic and picric acid

The losses of Group II (agarose gel, covered with filter paper) are due to insufficient fixation of proteins. We performed comparative tests on 3 groups with 12 agarose gel plates in order to investigate the fixing effect of picric acid and alcoholic acetic acid. At the same time, we examined whether the staining of proteins with Amido Black is influenced by treatment with the strong and intensely yellow picric acid.
The results given in table 3 show no significant differences for three different procedures: washing after fixation with alcoholic acetic acid (Group I) or picric acid (Group II) or covering with filter paper after fixation with picric acid (Group III). Treatment with picric acid does not influence the binding of Amido Black to the proteins. The results indicate that the strong fixing agent picric acid is only required if the buffer salts are extracted with filter paper. If the salts are extracted by washing, fixation with alcoholic acetic acid is sufficient.

\section{Investigation of suitable quantities of CSF} protein for evaluation of the pherograms under optimum conditions

Reproducible quantitative analysis is dependent upon two conditions. Firstly the complete registration of the strongly stained albumin peak in the linear portion of

Tab. 3. Comparison of the fixing effect of alcoholic acetic acid and picric acid; subsequent application of the two methods of buffer salts extraction. For explanation of the symbols see table 2 .

\begin{tabular}{|c|c|c|c|c|c|}
\hline Group & Fixing agent & $\begin{array}{l}\text { Method of buffer } \\
\text { salt extraction }\end{array}$ & Total protein & Albumin & Globulin \\
\hline I & Alcoholic acetic acid & $\begin{array}{l}\text { washing with } \\
\text { distilled water }\end{array}$ & $\begin{aligned} \overline{\mathrm{x}} & =2532 \mathrm{IE} \\
& =100 \%\end{aligned}$ & $\begin{aligned} \bar{x} & =1381 \mathrm{IE} \\
& =54.54 \% \\
s & =44.09 \mathrm{IE} \\
C V & =3.19 \%\end{aligned}$ & $\begin{aligned} \bar{x} & =1151 \mathrm{IE} \\
& =45.46 \% \\
s & =67.36 \mathrm{IE} \\
C V & =5.85 \%\end{aligned}$ \\
\hline II & Picric acid & $\begin{array}{l}\text { washing with } \\
\text { distilled water }\end{array}$ & $\begin{aligned} \overline{\mathrm{x}} & =2577 \mathrm{IE} \\
& =100 \%\end{aligned}$ & $\begin{aligned} \overline{\mathrm{x}} & =1421 \mathrm{IE} \\
& =55.14 \% \\
\mathrm{~s} & =68.78 \mathrm{IE} \\
\mathrm{CV} & =4.84 \%\end{aligned}$ & $\begin{aligned} \bar{x} & =1156 \mathrm{IE} \\
& =44.86 \% \\
s & =83.74 \mathrm{IE} \\
C V & =7.24 \%\end{aligned}$ \\
\hline III & Picric acid & $\begin{array}{l}\text { covering with } \\
\text { filter paper }\end{array}$ & $\begin{aligned} \cdot \overline{\mathrm{x}} & =2485 \mathrm{IE} \\
& =100 \%\end{aligned}$ & $\begin{aligned} \bar{x} & =1395 \mathrm{IE} \\
& =56.14 \\
\mathrm{~s} & =84.43 \mathrm{IE} \\
\mathrm{CV} & =6.05 \%\end{aligned}$ & $\begin{aligned} \bar{x} & =1090 \mathrm{IE} \\
& =43.86 \\
s & =86.26 \mathrm{IE} \\
C V & =7.91 \%\end{aligned}$ \\
\hline
\end{tabular}


the curve must be ensured, and secondly the globulin portion of the curve must be sufficiently high to permit evaluation.

The calibration curve obtained by applying $1.6 \mu \mathrm{l}$ sample to the $5 \mathrm{~mm}$ wide starting slit is linear up to a concentration of $120 \mathrm{~g} / 1(4.2 \mu \mathrm{g} / \mathrm{mm})$, resulting in an absorbance (A) of 1 at the apex of the peak. If the value of $A=1.4$ is exceeded, the curve flattens out. Taking into account an albumin/globulin quotient of approx. 1, we would not care to risk applying more than $40 \mu \mathrm{g}$ of CSF protein (1.6 $\mu \mathrm{l}$ in volume, corresponding to a concentration of $25 \mathrm{~g} / \mathrm{l})$ to the $5 \mathrm{~mm}$ wide starting slit $(8 \mu \mathrm{g} / \mathrm{mm})$ for electrophoresis.

Reproducible analysis requires that the average height of the globulin portion of the curve is not lower than $0.1 \mathrm{~A}$. When $8 \mu \mathrm{g} / \mathrm{mm}$ protein are applied and the resultant run evaluated at $482 \mathrm{~nm}$, the albumin fraction will be registered in full over the range corresponding to $1 \mathrm{~A}$, but the globulin portion of the curve will fall below $0.1 \mathrm{~A}$. We therefore carried out the analysis in two parts, registering the albumin and the globulin separately on curves plotted at different wave lengths. The run was registered at $482 \mathrm{~nm}$, to determine the albumin, and at $610 \mathrm{~nm}$, in the region of the maximum of the absorption curve of Amido Black $10 \mathrm{~B}$, to determine the globulin. The conversion factor of 3.71 was ascertained by repeatedly determining the integral of an albumin peak registered at $482 \mathrm{~nm}$ and $610 \mathrm{~nm}$.

\section{Determination of reference points for defining} the electrophoretic mobility of individual fractions

A prerequisite for the definition of the reference points is the determination of the positions of individual fractions of the electrophoretic curve. We selected a reference length of 60.5 between the application slit and the albumin fraction (see fig. 2). The applicability of the reference length was tested by defining the quotient of the lengths

$$
\frac{\text { albumin - application slit }}{\beta_{1} \text {-globulin - application slit }}
$$

of 21 pherograms (tab. 4, a). For comparison we used pure fractions of albumin and transferrin, and defined

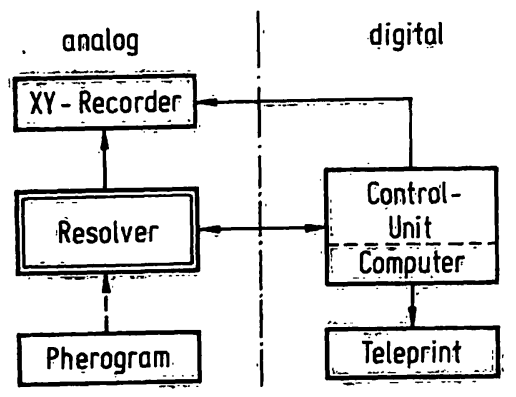

Fig. 2. Blockdiagram of the computer.
Tab. 4. Reproducibility of the reference lines for ascertaining the positions of the protein fractions.

$a=C S F$ concentrates; $b=$ albumin-transferrin mixture; $c=$ albumin-transferrin-dextran mixture; measuring points $=$ centre of application slit, centre of proteins or

\begin{tabular}{|c|c|c|c|}
\hline & $\begin{array}{l}\text { CSF } \\
a\end{array}$ & Pure & $\begin{array}{l}\text { fractions } \\
\text { c }\end{array}$ \\
\hline \multirow{2}{*}{$\mathrm{n}=21$} & Albumin-Slit & Albumin-Slit & Albumin-Dextran \\
\hline & $\beta 1-$ Globulin-Slit & Transferrin-Slit & Transferrin-Dextran \\
\hline$\overline{\mathbf{x}}$ & 1.585 & 1.579 & 2.078 \\
\hline s & 0.0173 & 0.020 & 0.0624 \\
\hline $\mathrm{CV} \%$ & 1.09 & 1.27 & 2.99 \\
\hline
\end{tabular}
dextran after electrophoresis.

their positions in relation to the application slit (tab. $4, \mathrm{~b})$ and furthermore to dextran, which had been added to the mixture of pure proteins (tab. $4, \mathrm{c}$ ). During electrophoresis, dextran, which is a reference substance without electric charges, moves towards the cathode due to electro-osmosis. By relating protein fractions to dextran, the electroosmotic shift is eliminated $(9,16)$.

Our results (tab. 4) demonstrate the efficacy of the reference length albumin to application slit. A variation coefficient of 1.09 or 1.27 was found in relation to the application slit, whereas the methodical error amounted to $2.99 \%$ in relation to dextran. The greater variation coefficient resulted from the difficulty in determining the exact centre of the dextran spot after electrophoresis. In all our studies, the reference length albumin to application slit proved to be sufficiently reliable, which means that the electrophoretic mobility of albumin as well as of transferrin is constant. We were able to obtain uniform electro-osmotic effects by using the same agarose charge and standard electrophoresis procedure.

Evaluation of the pherograms by analog computer and reproducibility of the results

To resolve pherogram curves into normal distributions by means of the analog computer, we first projected normal distributions into markedly protruding and therefore clearly defined fractions. If the upper twofifths of a protein fraction are apparent, the normal distribution can be completed without difficulty (17). Then the total pherogram was reconstructed by adding as few Gaussian distributions as possible, thus providing a reproducible analysis of largely overlapping protein fractions. In order to synthetize CSF pherograms, it was necessary in every case to summate 15 normal distributions. As an example of the evaluation, figure $3 \mathrm{a}$ shows the densitometer curve of a normal CSF pherogram, while figure $3 \mathrm{~b}$ shows the curve reproduced by the analog computer. Figure $4 a, b$ demonstrates the curve of a pathological CSF specimen in which $M$ components appear. 

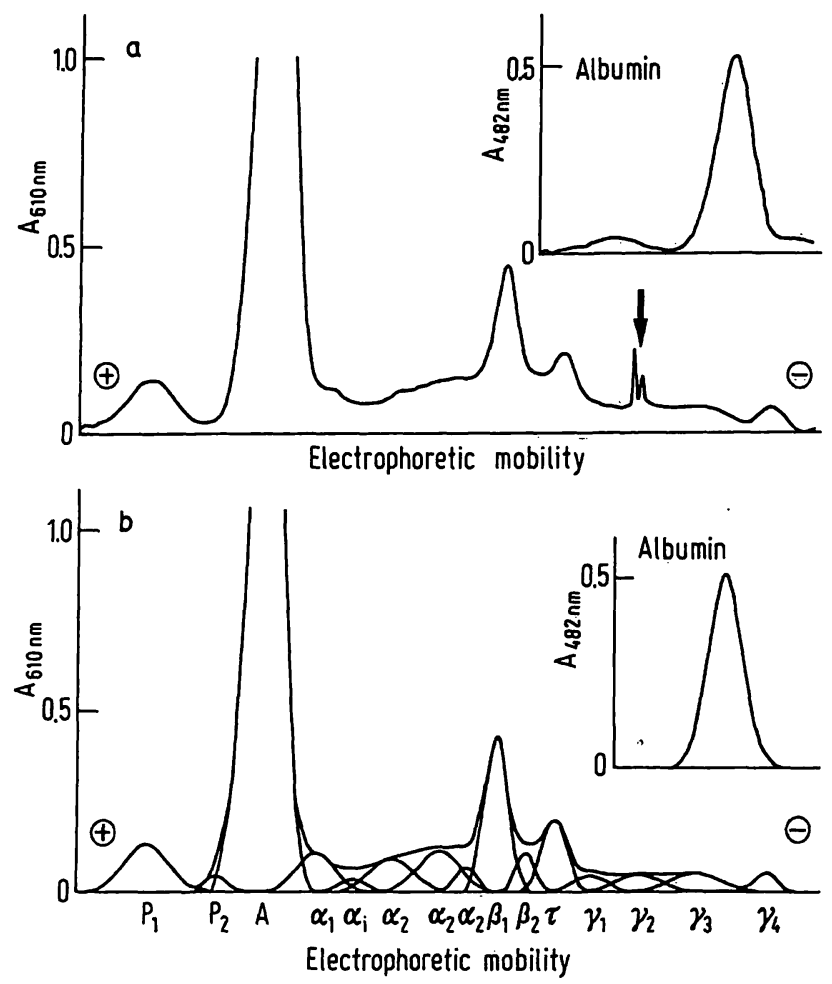

Fig. 3. a) Pherogram of normal CSF scanned at $610 \mathrm{~nm}$ for analysing prealbumins and globulins and at $482 \mathrm{~nm}$ for determining albumin, $\downarrow=$ application slit

b) Analog computer evaluation of the curve, conversion factor for the albumin values registered at $482 \mathrm{~nm}$ to those registered at $610 \mathrm{~nm}=3.71$; definition of the fractions according to Lowenthal $\left(\mathrm{P}_{1}, \mathrm{P}_{2}=\right.$ prealbumin, $\mathrm{A}=$ albumin)
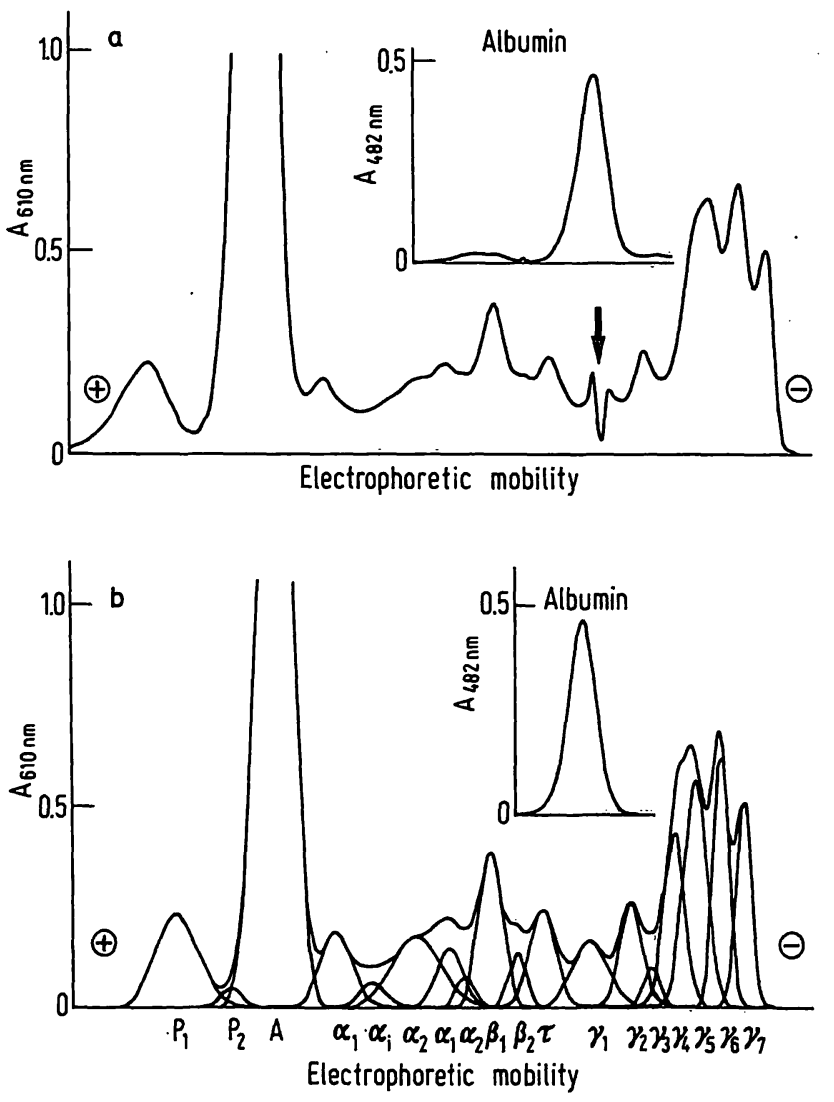

Fig. 4. CSF pherogram (a) and its analog computer analysis (b) of a 13-year-old girl with subacute sclerosing panencephalitis. Oligoclonal $\boldsymbol{\gamma}$-globulin bands are visible.
In order to test the reproducibility of our analytical technique, we analysed a single pherogram curve ten times with the analog computer. In addition, we combined electrophoresis with analog computer analysis by performing the operation ten times. The results are given in table 5. Comparison of the values indicates that the mean error for the smaller markedly overlapping fractions is twice to three times as great as that of the clearly defined and only slightly overlapping fractions. It follows that the greater the number of well-marked peaks in an electrophoretic profile, the more exact are the analytical results that can be expected.

Determination of normal values of CSF protein fractions in children

In order to demonstrate the effectiveness of the procedure, the results of determining normal values are presented in figure 5. For these investigations, CSF samples of 38 children selected from a larger group of patients were available; 3 pherograms were made from each sample. Figure 5 illustrates the average values of the positions as well as the relative percentages of the 15 fractions, together with their mean error $( \pm 2 S)$. As the analysis given in figure 3 demonstrates, 2 prealbumins, 1 albumin, $5 \alpha$-, $3 \beta$ - and $4 \gamma$-fractions were found in each case.

\section{Discussion}

Immunochemical methods are gradually superseding zone electrophoresis as a means of determining CSF and plasma proteins (18). Heremans \& Masson (19) point out the disadvantages of zone electrophoresis inherent in the fact that quantitative measurement is difficult with overlapping fractions and quite impossible when they are concealed. There is some doubt, however, as to whether immunochemistry is more suitable than electrophoresis for the determination of CSF proteins, since both methods are subject to some uncertainty.

Specific antiserums are not available for the immunochemical verification of all CSF proteins. Bock (20) emphasizes that for quantitative immunochemical determination, the molecular structure and the charge of antigen and standard must be identical. However, this is not so in the case of a number of proteins typically appearing in normal CSF e.g. the $\tau$ - and post $\gamma$-fraction, and under pathological conditions e.g. M-components, that are helpful in establishing the diagnosis of subacute sclerosing panencephalitis and multiple sclerosis $(1-6$, 21, 22). It is pointed out by Heremans \& Masson (19) and also by Daniels et al. (23) that the conventional electrophoresis is the most reliable method of determining M-components.

For the analysis of CSF proteins, the method of agar gel microelectrophoresis is used by a number of authors 
Tab. 5. a) Repeated analog computer analyses $(n=10)$ of a CSF pherogram with fixed position of 15 fractions; definition of integrals in $\mathrm{mV}$.

b) Repeated electrophoresis and subsequent analog computer analyses $(n=10)$ of a CSF specimen with 15 fixed positions of 15 fractions; definitions of integrator units in per cent.

\begin{tabular}{llllllllllllllll}
\hline Fraction & $\mathrm{P}_{1}$ & $\mathrm{P}_{2}$ & $\mathbf{A}$ & $\alpha_{1}$ & $\alpha_{\mathrm{i}}$ & $\alpha_{2}$ & $\alpha_{2}^{\prime}$ & $\alpha_{2}{ }^{\prime \prime}$ & $\beta_{1}$ & $\beta_{2}$ & $\boldsymbol{\tau}$ & $\gamma_{1}$ & $\gamma_{2}$ & $\gamma_{3}$ & $\gamma_{4}$ \\
\hline$\overline{\mathbf{x}}$ & 101 & 21 & 648 & 129 & 38 & 94 & 52 & 33 & 101 & 30 & 81 & 45 & 16 & 67 & 14 \\
$\mathrm{~s}$ & 2.3 & 2.0 & 12.2 & 4.0 & 2.5 & 3.9 & 3.4 & 2.0 & 3.0 & 2.1 & 2.2 & 3.5 & 1.0 & 1.7 & 1.0 \\
$\mathrm{CV} \%$ & 2.3 & 9.9 & 1.9 & 3.1 & 6.6 & 4.2 & 6.6 & 6.2 & 3.0 & 7.0 & 2.7 & 7.7 & 6.9 & 2.5 & 7.0
\end{tabular}

b)

\begin{tabular}{|c|c|c|c|c|c|c|c|c|c|c|c|c|c|c|c|}
\hline Fraction & $\mathbf{P}_{1}$ & $\mathbf{P}_{2}$ & $\mathbf{A}$ & $\alpha_{1}$ & $\alpha_{i}$ & $\alpha_{2}$ & $\alpha_{2}^{\prime}$ & $\alpha_{2}^{\prime \prime}$ & $\beta_{1}$ & $\beta_{2}$ & $\tau$ & $\gamma_{1}$ & $\gamma_{2}$ & $\gamma_{3}$ & $\gamma_{4}$ \\
\hline$\overline{\mathbf{x}}$ & 6.9 & 1.5 & 47.8 & 5.3 & 1.0 & 4.3 & 5.3 & 2.0 & 8.2 & 3.1 & 5.4 & 1.9 & 1.9 & 3.4 & 1.9 \\
\hline $\mathbf{s}$ & 0.41 & 0.25 & 2.42 & 0.42 & 0.10 & 0.35 & 0.43 & 0.23 & 0.61 & 0.33 & 0.37 & 0.27 & 0.16 & 0.19 & 0.16 \\
\hline CV\% & 6.0 & 16.0 & 5.1 & 7.9 & 9.6 & 8.2 & 8.1 & 11.4 & 7.5 & 10.7 & 6.9 & 14.0 & 8.4 & 5.6 & 8.4 \\
\hline
\end{tabular}

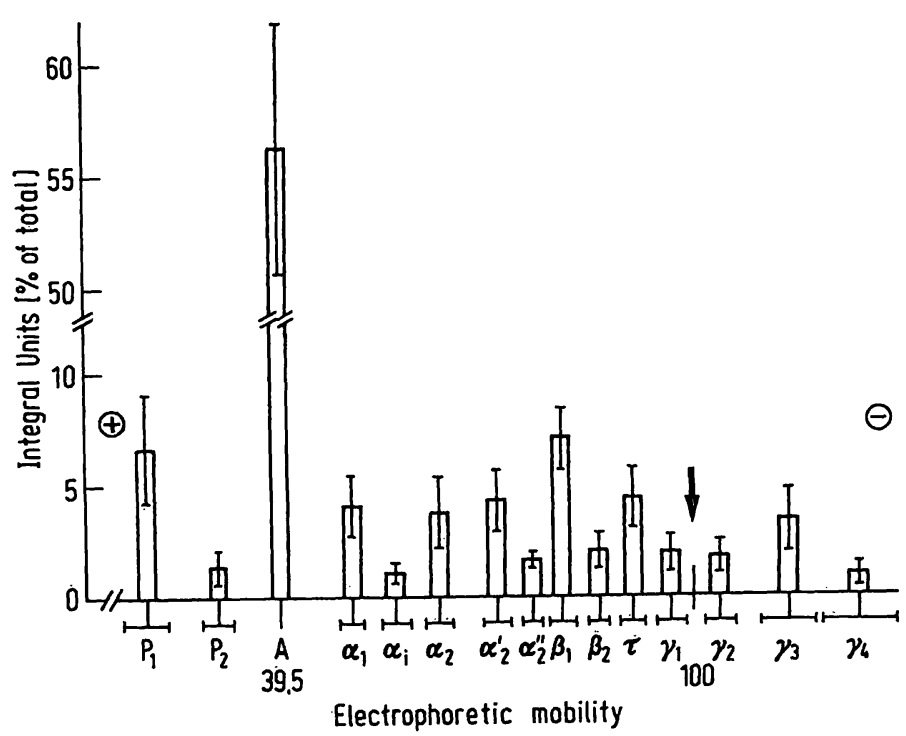

Fig. 5. Arithmetic mean and standard deviation $(\bar{x} \pm 21)$ of relative concentration(\% of total protein) of individual CS F fractions as well as arithmetic mean and standard deviations of their electrophoretic mobility $(\bar{x} \pm 21)$ of children; 2-14 years of age, without central nervous system diseases. $\downarrow$ application slit

in the diagnosis of neurological disorders $(1-3,6,7-13$, $21,22,24)$. Provided that certain sources of error are taken into account, this supporting medium is eminently suitable for quantitative electrophoresis. Agar gel is optically empty, and it permits the reproducible, uniform application of specific quantities of protein. As a result of electroendosmosis, the immunoglobulins show up more clearly separated from the $\beta$ fractions than is the case with other methods.

The great advantages of using agar gel as a supporting medium are offset to some extent by the disadvantage that, being extracted from red marine algae, it is not chemically homogeneous and may display wide variations in quality, depending on the species of agarophytes and differences in growth factors. According to Duckworth \& Yaphe (25), agar consists of three components, the virtually neutral, quick-setting agarose, which has a molecular structure composed of alternating sequences $(1-4)$ linked 3.6-anhydro- $\alpha$ - $L$-galactose and $(1-3)$ linked $\beta$ - $D$-galactose; a fraction in which the $D$-galactose residues are replaced by $4.6-0$-(1-carboxyethylidene)$D$-galactose; and a sulphated galactan containing little or no 3.6-anhydro- $L$-galactose or 4.6-0-(1-carboxyethylidene)-D-galactose residues. According to Hierholzer (26) electroosmotic reflux has a direct relationship to the sulphate content of the gel, the negative charge of which is attributable mainly to the sulphate anions.

Agar is used by the majority of authors as the supporting medium, because of its more pronounced displacement of the immune globulins in the direction of the cathode. In our model experiments on serum proteins, which can also be taken to apply to CSF proteins, we have been able to demonstrate that the use of agar gel results in falsification of the results of electrophoresis by reason of a shift in the albumin/globulin relationship obviously caused by the high anion content of the supporting medium. The albumin, present in a highly concentrated form in a confined space in electrophoresis, is less affected by the blockage of the stainabsorbing protein groups than the globulins, which are widely distributed at low concentration in the run. Agar contains up to $11 \mathrm{~g} / \mathrm{kg}$ sulphate. Quantitative electrophoresis requires the use of an agarose with a sulphate content of 1 to $2 \mathrm{~g} / \mathrm{kg}$ which, on the one hand, has an osmosis capability adequate for depiction of the immune globulins and on the other does not affect the stainability of the proteins. Link (27) has likewise referred to the usefulness of agarose for the examination of $\boldsymbol{\gamma}$-globulin abnormalities in CSF and serum.

For our tests, we made use of Amido Black $10 \mathrm{~B}$, after it had proved that, contrary to the results published by other authors $(28,29)$, this easily handled stain, 
although chromatographically unhomogenous, is quite suitable for quantitative determination (30).

The results of quantitative agar gel electrophoresis are subject to other influences besides that of the supporting medium; the methods of protein fixation and extraction of the buffer salts can have a much more pronounced effect. In model experiments on serum proteins, we were able to demonstrate that after fixation with alcoholic acetic acid, the removal of buffer salts with filter paper resulted in a considerable loss of proteins with agarose and a slight loss with agar. It is obvious that the acid substituted groups of the polysaccharide chains effected an additional fixation of the proteins in the gel matrix. Falsification of the quantitative electrophoresis through faulty preparation of the carriers can be avoided by two methods which, although producing results with coincident figures, are not equally applicable:

1. Fixation with picric acid according to Davidsen (31) and removal of buffer salts with filter paper;

2. Fixation with acetic acid and gentle removal of buffer salts by washing with distilled water.

We prefer the latter method, as densitometry is not affected by scraps of filter paper on the surface of the gel carrier, and the necessity of handling strong dyes is avoided. Moreover, preparation of the carriers by automatic means is possible with this method. Not all authors take the Lambert-Beer law into account in the quantitative interpretation of the pherograms. The uneven distribution of the albumin and the globulins per unit area can give rise to serious falsification of the results of quantitative analysis. This is particularly the case when excessive quantities of protein $(15-20 \mu \mathrm{g} / \mathrm{mm})$ are applied to the starting slit in an attempt to obtain a clear representation of the globulins, e.g. the M-components. In such cases, the dense colour zone of the albumin lies outside the linear portion of the calibration curve. Precise quantitative determination of the diagnostically relevant proteins is ensured by reducing $1-3 \mathrm{ml}$ of CSF to $50 \mu \mathrm{l}$ and applying 2-8 $\mu \mathrm{g}$ total protein per $\mathrm{mm}$ starting slit, provided that our evaluation method of registering the albumin peak and the globulin curve in two stages is followed. In this connection, it is pointed out that the application of very small quantities of protein on the order of ca. $0.2 \mu \mathrm{g}$ per mm, as proposed by Kleine \& Stroh (32), and Glasner (33), embodies the risk of non-registration of diagnostically important fractions.

The quantitative interpretation of the pherograms is dependent on the precise demarcation of the fractions which in fact define the electrophoresis profiles. In the interest of efficiency and the avoidance of subjective errors, automatic and semi-automatic densitometers have been developed. It is general practice when working with commercially obtainable equipment to use perpendiculars drawn through the lowest points as criteria for the demarcation of overlapping fractions. However, according to Lincke (34), this procedure can result in gross errors, for the reason that the essential prerequisite, namely identical size of the overlapping fractions, does not normally exist. The construction of perpendiculars and the formerly used graphic separation of the fractions are rough and ready methods of measuring visible fractions only, while concealed and semi-concealed fractions remain undetected.

Several authors $(5,18,19)$ have drawn attention to the problems associated with electrophoresis profiles and thus with conventional electrophoresis as a quantitative method.

To break down electrophoresis profiles into individual fractions with any semblance of accuracy is an impossible task without the aid of an analog or digital computer. Programmes for the analysis of sum distributions by digital computers using the least-square method (35, 36) have already been described in connection with the resolution of profiles from chromatograms and more recently the profiles of pherograms $(37,38)$. Precise analysis necessitates elaborate programmes d̀nd a great expenditure of time, as demonstrated by Tränkle $(39,40)$ in the analysis of electrophoresis and ultracentrifuge patterns with the CDC CYBER 7200 Computer.

For our investigations, we modified the analog computer described by Noble \& Hayes (41), of which more details are given in the section "METHODS". With this unit, the direct data input of the integral of the albumin peak and the correction of the profile in the application zone is quite straightforward. The separate registration, analysis and integration of the albumin and the globulins permits precise quantification of even quite small globulin fractions.

The price of the computer is roughly equivalent to that of commercially available evaluation units. The time required for analysis is approximately 10 minutes, much of which is taken up in setting the potentiometers to reproduce the pherogram profiles. A considerable amount of time could be saved if the analysis could be carried out digitally after analog data preparation.

A preliminary condition for the digital and analog analysis of the pherograms of pathologically altered CSF proteins is knowledge of the function, number and position of the fractions constituting the normal electrophoresis profile. We were able to demonstrate by preliminary experiments on pure proteins that their fractions in the pherogram were present and correct in the form of normal distributions under the given electrophoresis conditions.

In the measurement of the relative electrophoretic mobility of the fractions, it is usual to take the distance between the position of a reference protein and the 
application slit. The reference protein should display the greatest possible electrophoretic mobility, a condition which is obtained by acetylating the albumin (42) or carbamylating the transferrin (43). To determine the extent of electro-osmosis, the distance between the application slit and a non-charging substance, such as dextran, is usually measured $(9,16)$. The reference protein and the non-charging substance are separated in a second run of the same carrier by most authors.

For reasons of reproducibility and simplicity, the reference protein should be contained in the test sample. Separate application to the starting slit is difficult, and there is no absolute certainty that the quantification of the CSF proteins will not be influenced by the reference protein.

In our investigations, we were able to demonstrate that the albumin in the CSF is a suitable reference substance. This is supported also by investigations carried out on numerous CSF specimens.

In order to register the prealbumins in front of this fraction in the electrophoretic run, the reference distance of the computer is set so that the 39.5 value always corresponds to the centre of the albumin fraction and the 100 value to the application slit. It is not necessary to determine electro-osmosis for every electrophoresis, provided that the same agarose is used every time and the separation conditions are kept absolutely constant.
It is sufficient merely to ascertain the degree of electroosmosis prior to introducing each new charge.

Our investigations revealed that 15 fractions are necessary for the reconstruction or resolution of normal CSF protein profiles by analog computer. Of these, 2 are found in the prealbumin, 1 in the albumin, 5 in the $\alpha-, 3$ in the $\beta$-globulin range and 4 in the immune globulin range. As was expected, overlapping and concealed distributions are subject to greater methodical error than the clearly defined fractions, e.g. those of the prealbumin, the albumin and the $\alpha 1-, \alpha 2-, \beta 1-, \tau$ - and $\gamma-3$ fractions. We felt justified in graduating the pherogram profiles as stated, as literature references to the number of the fractions contained in agar pherograms are not by any means consistent. The resolution of electrophoresis profiles is carried out by the majority of authors in more or less arbitrary fashion analogous to the nomenclature of the constellation of the serum proteins and incorporating the $\tau$ - and post $\gamma$-fractions typically found in CSF.

Analysis of the pherogram profiles obtained under standard conditions on the basis of the summation of a specific number of normal distributions and adherence to fixed positions has proved, as the result of investigations on over 1500 CSF specimens, to be useful in throwing light on the relationship between the protein constellation of the CSF and pathological conditions of the central nervous system.

\section{References}

1. Bader, R., Rieder, H. P. \& Kaeser, H. E. (1973), Z. Neurol. 206, 25-38.

2. Link, H. (1973), Ann. Clin. Res. 5, 330-336.

3. Vandvik, B. \& Skrede, S. (1973), Europ. Neurol. 9, 224-241.

4. Ansari, K. A., Wells, K. \& Vatassery, G. T. (1975), Neurology, Minneap. 25, 688-692.

5. Olsson, J. E., Pettersson, B. (1976), Acta Neurol Scand. 53, 308-322.

6. Johnson, K. P., Arrigo, S. C., Nelson, B. J. \& Ginsberg, A. (1977), Neurology 27, 273-277.

7. Lowenthal, A. (1964), Agar Gel Electrophoresis in Neurology. Elsevier Publishing Company, Amsterdam-LondonNew York.

8. Laterre, E. C. (1965), Les Proteinés du liquide céphalorachidien à l'etat normal et pathologique. Edition Arscia, SA Bruxelles.

9. Wieme, R. J. (1965), New York, Agar Gel Electrophoresis. Elsevier Pụblishing Cómpany, Amsterdam-Londọn.

10. Link, H. (1967), Acta Neurol. Scand. 43, Suppl. 28, 1-136.

11. Laurell, C. B. (1972), Scand. J. Clin. Lab. Invest. 29, Suppl. $124,71-82$.

12. Rieder, H. P., Jung, P. R. \& Burri, V. (1972), Z. Klin. Chem. Klin. Biochem. 10, 379-384.

13. Siemes, H., Siegert, M., Rating, D. (1975), Neuropädiatrie, 6, 383-397.

14. Mattenheimer, H. (1961), Mikromethoden für das klinischchemische und biochemische Laboratorium. Walter de Gruyter \& Co., Berlin.

15. Siegert, M. (1977), Protides of the Biological Fluids, 25 th Colloquium, Pergamon Press, in press.

16. De Boer, W., Hoenders, H. J., De Boer, P. A. J. \& Toorop, H. A. (1967), Clin. Chim. Acta 5, 533-540.

17. Ribeiro, L. P., Mitidieri, E. \& Alfonso, D. R. (1961), Paper Electrophoresis, Elsevier Publishing Company, AmsterdamLondon-New York.

18. Laurell, C. B. (1973), Clin. Chem. 19, 99-102.

19. Heremans, J. F. \& Masson, P. L. (1973), Clin. Chem. 19, 294-300.

20. Bock, E. (1973), Scand. J. Immunol. 2, Suppl. 1, 111-117.

21. Link, H. (1973), Ann. Clin. Res. 5, 330-336.

22. Johnson, K. P., Arrigo, S. C., Nelson, B. J. \& Ginsberg, A. (1977), Neurology 27, 273-277.

23. Daniels, J. C., Vyvial, T. M., Levin, W. C. \& Ritzmann, S. E. (1975), Clin. Chem. 21, 243-248.

24. Laurell, C. B. (1972), Scand. J. Clin. Lab. Invest. 29, Suppl. 124, 21-37.

25. Duckworth, M. \& Yaphe, W. (1971), Anal. Biochem. 44, 636-641.

26. Hierholzer, J. C. (1976), J. Immunol. Methods 11, 63-76.

27. Link, H. (1973), Clin. Chim. Acta 46, 383-389.

28. Busse, V. (1968), Z. Klin. Chem. Klin. Biochem. 6, 273-277.

29. Busse, V. \& Dulce, H. J. (1969), Z. Klin. Chem. Klin. Biochem. 7, 486-492.

30. Siegert, M., Schützler, G. \& Jarofke, R. (1976), Clin. Chim. Acta 73, 423-430.

31. Davidson, O. (1968), Clin. Chim. Acta 21, 205-209.

32. Kleine, T. O. \& Stroh, J. (1974), Z. Klin. Chem. Klin. Biochem. 12, 73-80.

33. Glasner, H. (1977), Klin. Wochenschr. 55, 181-187.

34. Lincke, W. (1969), G. I. T. Fachz. Lab. 13, 423-425.

35. Savitzky, A. \& Golay, M. J. E. (1964), Anal. Chem. 36, 1627-1639. 
36. Fraser, R. D. B. \& Suzucki, E. (1966), Anal. Chem. 38, 1770-1773.

37. Scott, C. D. \& Chilcote, D. D., Pitt, W. W. jr. (1970), Clin. Chem. 16, 637-642.

38. Taylor, R. \& Davis, M. G. (1973), Anal. Biochem. 51, 180-192.

39. Tränkle, E. (1975), Z. Naturforsch. 30 c, 311-317.
40. Tränkle, E. (1975), Comp. Progr. Biomed. 5, 39-45.

41. Noble, J. W., Hàyes, J. E. \& Eden, M. (1964), Ann. N. Y. Acad. Sci. 115, 644-652.

42. Clarke, H. G. M. \& Freeman, T. (1968), Clin. Sci. 35, 403-406.

43. Weeke, B. (1970), Scand. J. Clin. Lab. Invest. 25, 161-163.

Prof. Dr. M. Siegert

Bitterstri. 14

D-1000 Berlin 33 